Nig. J. Biotech. Vol. 36(2): 9 - 20 (Dec 2019)

ISSN: 01891731

Available online at

http://www.ajol.info/index.php/njb/index

and www.biotechsocietynigeria.org

DOI: https://dx.doi.org/10.4314/njb.v36i2.2

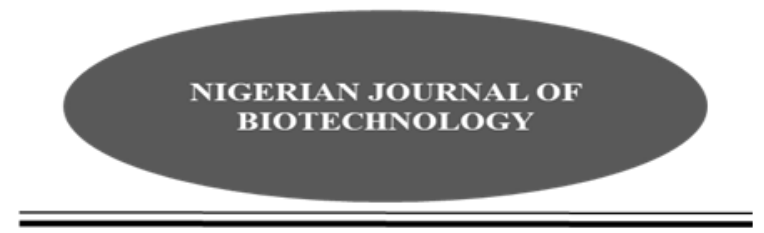

\title{
Screening of Cowpea (Vigna unguiculata ( L.)Walp) Varieties for Resistance to Leaf Spot in Southern Guinea Savannah Agro- Ecology of Nigeria.
}

\author{
*Ekhuemelo, C., Igbor, H.U and Ocheje, S.J. \\ Department of Crop and Environmental Protection, Federal University of Agriculture, P.M.B. 2373 Makurdi, \\ Benue State, Nigeria.
}

\begin{abstract}
Five cowpea varieties (Vigna unguiculata (L.) Walp) namely UAM 09 1055-6, UAM 09 10511, IT 99k-573-1-1, IT 90k-277-2 and IT 99k-573-2-1 were investigated for fungi associated with the seed, leaf spot disease incidence and severity in Makurdi $\left(07^{\circ} 45^{\prime}-7^{\circ} 50^{\prime} \mathrm{N}\right.$ and $08^{\circ} 45^{\prime}-08^{\circ} 50^{\prime} E$; $98 \mathrm{~m}$ )and Otobi $\left(7^{\circ} 07^{\prime}-7^{\circ} 11^{\prime} \mathrm{N}\right.$ and $8^{\circ}$ 05- $\left.8^{\circ} 10^{\prime} E\right)$ in Benue State, Nigeria under natural infection. The effect ofleaf spot incidence and severity on the growth and yield of cowpea varieties were also evaluated. Fungi associated with the seeds and leaf spot lesions were isolated and identified. Diseased leaf samples from the study locations were found to be infected with Fusarium verticillioides, Curvularia lunata, Aspergillus tamarii Kite, Lasiodiplodia theobromae, Aspergillus flavus Link and Aspergillus niger van Tiegh, Pythium spp, Fusarium solani, Macrophomina phaseolina and Phoma sp. Otobi field had significantly higher incidence and severity of leaf spot disease than the Makurdi field. Cowpea variety IT 99k-573-1-1, IT 99k-573-2-1 and IT 90k-277-2 were classified as moderately resistant in Makurdi with a mean incidence of $22.23 \%, 16.97 \%$ and $16.67 \%$ respectively while varieties UAM 09 1051-1 and UAM 09 1055-6 were classified as Moderately susceptible and Highly susceptible with mean leaf spot incidence of $41.67 \%$ and $\mathbf{9 9 . 1 7 \%}$ respectively. In Otobi, all the cowpea varieties screened were classified as Susceptible to leaf spot incidence with the exception of variety IT 90k-277-2 which was classified as moderately susceptible to leaf spot disease.
\end{abstract}

Key words: Cowpea, leaf spot, screening, resistant, susceptible.

*Corresponding author Email: chiekhuemelo@gmail.com

\section{Introduction}

Cowpea (Vigna unguiculata (L) Walp) is a legume widely cultivated in the tropics. Its grain is consumed as a source of cheap dietary protein while the tender leaves and immature pods are also eaten as vegetables (Dugje et al., 2009).In addition, the plant serves to provide fodder for livestock. Nigeria is the largest cowpea producer in Africa where cowpea is a source of livelihood for many subsistent farmers (Neya et al., 2015). In Nigeria, Cowpea is cultivated in the drier areas including Benue State where the rainfall range is between 500 and $1200 \mathrm{~mm} /$ year (Agber et al., 2017). The extra-early and early maturing cowpea varieties also thrive in the Sahel where the rainfall is less than $500 \mathrm{~mm}$ (Dugje et al., 2009).Cowpea production is affected by the incidence of pests and diseases at different stages of development. Leaf spot incidence on cowpea limits the leaf available for photosynthesis resulting in reduced yield. Yield losses of between $20 \%$ and $40 \%$ have been reported on cowpea due to leaf spot disease (Boa, 2014). Although Pseudocercospora cruenta or Mycosphaerella cruenta which are air borne 
(Boa, 2014) have been previously known as the causal agent of leaf spot on cowpea, the disease maybe caused by other fungal pathogens due to the emergence of new leaf spot fungi infecting cowpea. There is the need to identify these fungi and to screen the field response of some new cowpea varieties and existing varieties to leaf spot infection in Makurdi and Otobi in the Southern Guinea Savanna of Benue State, Nigeria. This study seeks to determine the seed health and viability of five cowpea varieties and to evaluate the response of these varieties of cowpea to infection by these fungi under natural infections.

\section{Materials and Methods}

Seed health testing.

Seed health of Cowpea varieties collected from the seed bank of the Molecular Biology Laboratory of Federal University of Agriculture, Makurdi, Nigeria was evaluated. Germination of seeds was done following the International Seed Testing Association guidelines.

\section{Isolation and identification of seed borne fungi}

The blotter method was used in isolating seed borne fungi. Cowpea seeds were sterilized in $10 \%$ Sodium hypochlorite for 1 minute and rinsed in three changes of sterile distilled water (SDW). Ten seeds were placed on moist blotter in sterilized $9 \mathrm{~cm}$ diameter Petri dishes moistened with $10 \mathrm{ml}$ SDW and incubated for seven days at ambient conditions of light and temperature. A total of ten replicates were maintained for each of the five varieties giving a total of 500 seeds arranged in a completely randomized design. The incubated seeds were observed for germination and fungal infection. Fungal isolates were further sub-cultured on PDA to obtain pure cultures. Isolated fungi were identified using manual and confirmed with the Germplasm Health unit of the International Institute of Tropical Agriculture (IITA) Ibadan, Nigeria.

Screening of Cowpea varieties for leaf spot infection under natural infection

Two field trials were set up simultaneously at the Teaching and Research Farm of the Department of Crop and Environmental Protection (07 $45^{\prime}$ $7^{\circ} \quad 50^{\prime} \mathrm{N}$ and $08^{\circ} 45^{\prime}-08^{\circ} 50^{\prime} \mathrm{E} ; 98 \mathrm{~m}$ ) and National Root Crops Research Institute Otobi Sub-station Benue State, located between $7^{\circ} 07^{\prime}$ - $7^{\circ} 11^{\prime} \mathrm{N}$ and $8^{\circ}$ 05- $8^{\circ} 10^{\prime}$ Ein the Southern
Guinea Savannah of Nigeria.Two newly released varieties (UAM 09 1055-6 and UAM 09 1051-1) and three cowpea varieties (IT 99k-573-1-1, IT 90k-277-2, IT 99k-573-2-1) obtained from the Molecular Biology laboratory of Federal University of Agriculture, Makurdi were evaluated in the locations.

The sites fall within the Southern Guinea Savannah agro-ecological zone of Nigeria, where the rainfall is bi-modally commencing between March/April and terminating in October/November with the highest peak in July/August. The total annual rainfall is about between $900 \mathrm{~mm}$ to $1200 \mathrm{~mm}$ and maximum and minimum temperatures of $37^{\circ} \mathrm{C}$ and $21^{\circ} \mathrm{C}$, respectively, while the relative humidity is between 70-80\% (Agber et al., 2017).

\section{Experimental Treatment and Design}

The experiment evaluated five cowpea varieties which were laid out in a Randomized Complete Block Design with three replications on a field of $17 \mathrm{~m} \times 13 \mathrm{~m}\left(221 \mathrm{~m}^{2}\right)$ with plot sizes of $3 \mathrm{~m} \times$ $4 \mathrm{~m}\left(12 \mathrm{~m}^{2}\right)$. The site was manually cultivated before planting. Two newly releasedcowpea varieties UAM 09 1055-6 (early maturity) and UAM 09 1051-1 and three other cowpea varieties IT 99k-573-1-1(Medium maturity), IT 90k-277-2 (Medium maturity), IT 99k-573-2-1 obtained fromthe Molecular Biology laboratory of the Federal University of Agriculture, Makurdiwere used.

Three seeds were planted per hill at an intra row spacing of $30 \mathrm{~cm}$ and inter row spacing of $75 \mathrm{~cm}$. The Cowpea seedlings were later thinned to two seedlings per hill. Single Super Phosphate fertilizer (SSP) was applied at the recommended rate of $30 \mathrm{~kg} / \mathrm{ha}$ at planting and NPK 15: $15: 15$ fertilizer at the rate of $15 \mathrm{~kg} / \mathrm{ha}$ at 4 weeks after planting (WAP). Weeding was done at 3 and 5 weeks after planting. Cowpea field was sprayed with Cypermethrin and dimethoate insecticide at the rate of $50 \mathrm{~g} \mathrm{a.i/ha}$ at 3, 6, 7 and 8 weeks after planting.

\section{Isolation and Identification of fungi}

Cowpea leaf samples with necrotic spots were collected from the two locations for isolation and identification of fungi. Small sections $(3-5 \mathrm{~mm}$ ) were cut from the edges of infected leaves to contain both diseased and healthy tissues. The 
tissues were sterilized for 1minute in $10 \%$ Sodium hypochlorite solution after which they were rinsed in three changes of SDW and blotted dry on sterile filter papers. Potato Dextrose Agar (PDA) was prepared by adding $39 \mathrm{~g}$ in 1 litre of Sterile Distilled Water (SDW) in a conical flask. The flask was autoclaved at $121^{\circ} \mathrm{C}$ for 15 minutes; the media was allowed to cool. Streptomycin Sulphate was added at the rate of $0.2 \mathrm{~g} / \mathrm{L}$ and the media allowed to solidify. The plates were then incubated on the laboratory bench at ambient conditions of light and temperature $\left(30 \pm 2^{\circ} \mathrm{C}\right)$ for 3 days. Pure culture was obtained by sub culturing unto fresh PDA plates.

Microscopic examination was done by examining the colony characteristics. A sterile needle

was used in taking a little portion of the hyphae containing spores on the sterile glass slide stained with lactophenol cotton blue and examined under the microscope for fungal structures. Pure cultures were identified using compound microscope and compared with reference manual (Wanatabe, 2010). The cultures were further confirmed at the Germplasm Health Unit of the International Institute of Tropical Agriculture (IITA) Ibadan, Nigeria.

\section{Data Collection}

Incubated seeds were examined for the presence of fungi to determine the seed health. Infected seeds were counted and recorded as percentages.

For the field screening, data collection was from the two inner rows. Data collection wason emergence percentage, disease incidence and severity, plant height, number of branches, number of leaves, number of pods per plant, days to maturity, number of days to $50 \%$ flowering, pod weight, pod, number of seeds pod, pod length ,100 seed weight, yield plot were recorded per plot.

Disease incidence

Disease incidencewas assessed by counting the number of infected plants in relation to the total number of plants per plot expressed as a percentage at 5, 8 and 11WAP corresponding to vegetative, flowering and pod stages.

\section{Disease severity per plot}

Disease severity was taken at 5, 8 and 11 weeks after planting. The average severity score was taken on each plot using the key from Onuegbu and Emiri (2011):

$0=$ leaves without spot.

$1=$ leaves with less than 5 spots.

$2=$ leaves with $5-10$ spots.

$3=$ leaves with more than 10 spots.

$4=$ dead leaves.

\section{Leaf spot Disease Rating}

The reaction of the Cowpea varieties to leaf spot disease across the two locations was evaluated using a modified rating scale adopted from Oladiran (1983):

$0=$ No leaf spot (Highly Resistant)

$1-25 \%$ leaf spot (Moderately Resistant)

26-50\% leaf spot (Moderately Susceptible)

$51-75 \%$ leaf spot (Susceptible)

$>76 \%$ leaf spot (Highly Susceptible)

\section{Data analysis}

Data were subjected to analysis of variance using Genstat 9th edition. Significant means were separated using Fishers least significant difference ( $F$ - LSD) at $5 \%$ level of probability. The emergence and growth data for both locations were averaged and analyzed.

\section{Results}

The data presented in Table 1 shows the fungi isolated from cowpea seeds before planting.Aspergillusflavus was isolated from all the cowpea varieties with highest isolation frequency of $6.40 \%$ followed by Fusarium verticillioides which was isolated from all cowpea varieties with a frequency of $2.00 \%$ and absent on IT 99k-573-2-1. Fusarium solani and Curvularia lunata were each isolated only from cowpea variety IT99k-573-1-1 and IT90k-277-2 respectively. 
Ekhuemelo et al ./ Nig. J. Biotech. Vol. 36 Num. 2 : 9 - 20 (December 2019)

Table 1: Fungi isolated from seeds of five cowpea varieties and their frequency of isolation in Makurdi

\begin{tabular}{|c|c|c|c|c|c|c|c|}
\hline \multirow[b]{2}{*}{$\begin{array}{l}\text { Fungi } \\
\text { Isolated }\end{array}$} & \multicolumn{5}{|c|}{ Cowpea variety } & \multirow[b]{2}{*}{$\begin{array}{l}\text { Total no. } \\
\text { of times } \\
\text { isolated }\end{array}$} & \multirow[b]{2}{*}{$\begin{array}{l}\text { Isolation } \\
\text { frequency (\%) }\end{array}$} \\
\hline & $\begin{array}{l}\text { IT99k- } \\
\text { 573-1-1 }\end{array}$ & $\begin{array}{l}\text { IT90k- } \\
277-2\end{array}$ & $\begin{array}{l}\text { UAM } 09 \\
1051-1\end{array}$ & $\begin{array}{l}\text { UAM } \\
09 \\
1055-6\end{array}$ & $\begin{array}{l}\text { IT99k- } \\
\text { 573-2-1 }\end{array}$ & & \\
\hline F. solani & + & - & - & - & - & 1 & 0.20 \\
\hline A. flavus & + & + & + & + & + & 32 & 6.40 \\
\hline A. niger & + & + & + & - & + & 8 & 1.60 \\
\hline F. verticillioides & + & + & + & + & - & 10 & 2.00 \\
\hline $\begin{array}{l}\text { A. flavus/ F. } \\
\text { Verticillioides }\end{array}$ & - & - & + & - & + & 2 & 0.40 \\
\hline Curvularia Iunata & - & + & - & - & - & 1 & 0.20 \\
\hline
\end{tabular}

$+=$ Present; - = Absent

Isolation of fungi associated with Leaf spot Lesions of Cowpea Varieties

A total of eight genera were isolated from the infected cowpea leaves and seeds. Cultural

\begin{tabular}{|l|l|l|l|}
\hline S/N & Fungi & Mycelium growth & Microscopic description \\
\hline 1. & Pythium sp from the & & \\
leaves of IT 99k 573-1-1 & & & \\
\hline
\end{tabular}

characteristics of fungi associated with cowpea seed and leaf spot in Makurdi and Otobi are presented in plates 1- 14. 
Ekhuemelo et al ./ Nig. J. Biotech. Vol. 36 Num. 2 : 9 - 20 (December 2019)

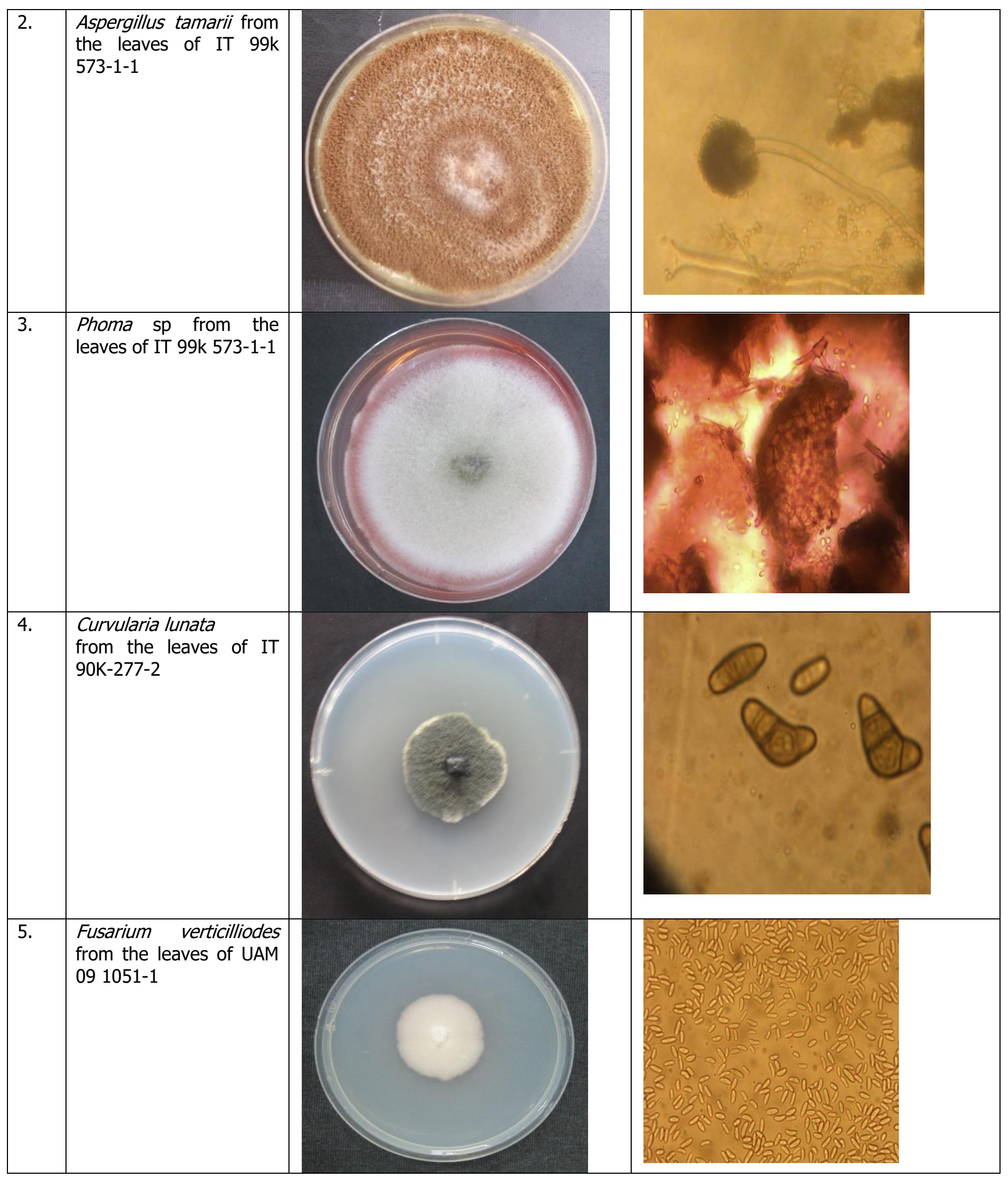


Ekhuemelo et al ./ Nig. J. Biotech. Vol. 36 Num. 2 : 9 - 20 (December 2019)

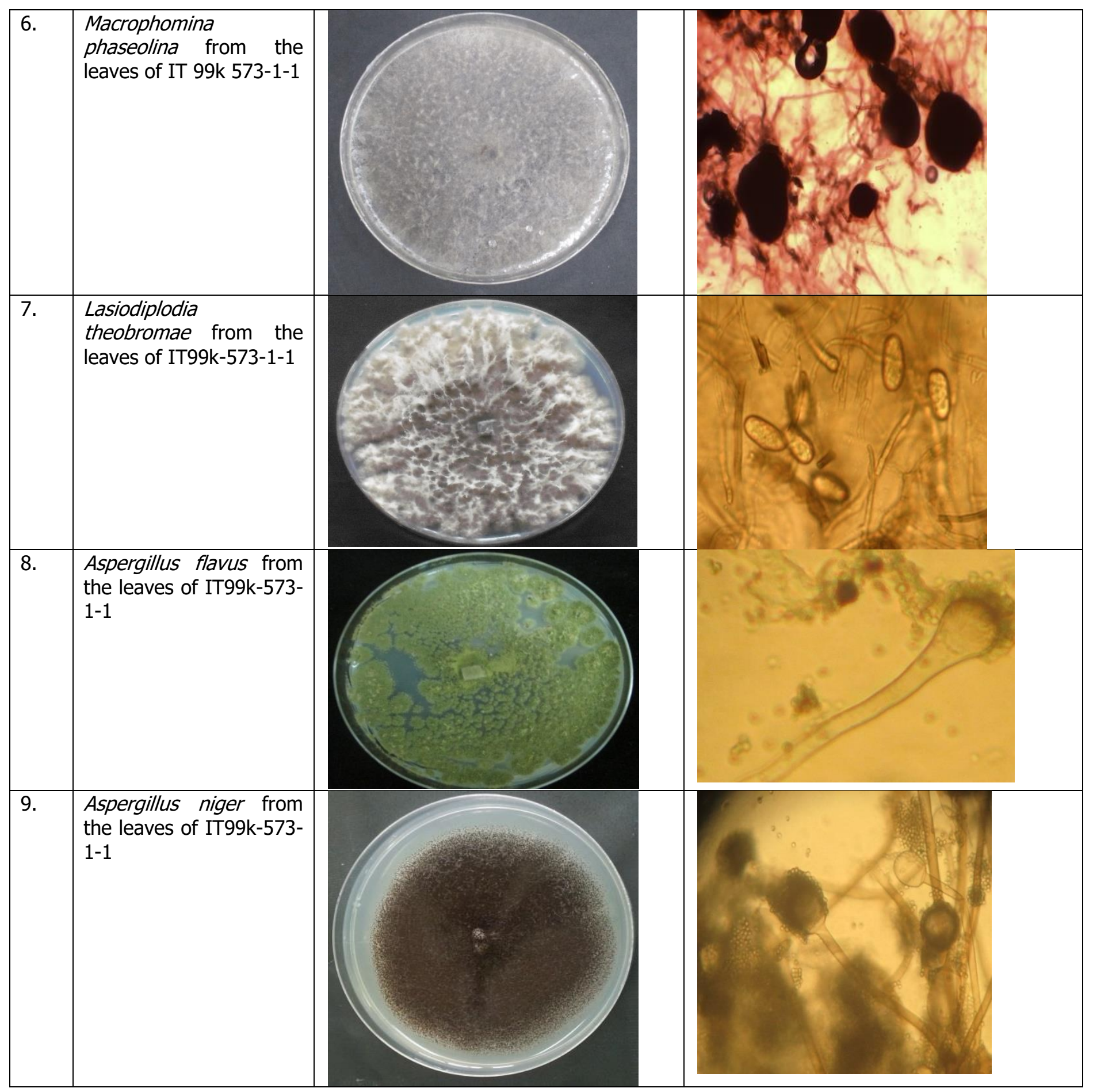


Ekhuemelo et al ./ Nig. J. Biotech. Vol. 36 Num. 2 : 9 - 20 (December 2019)

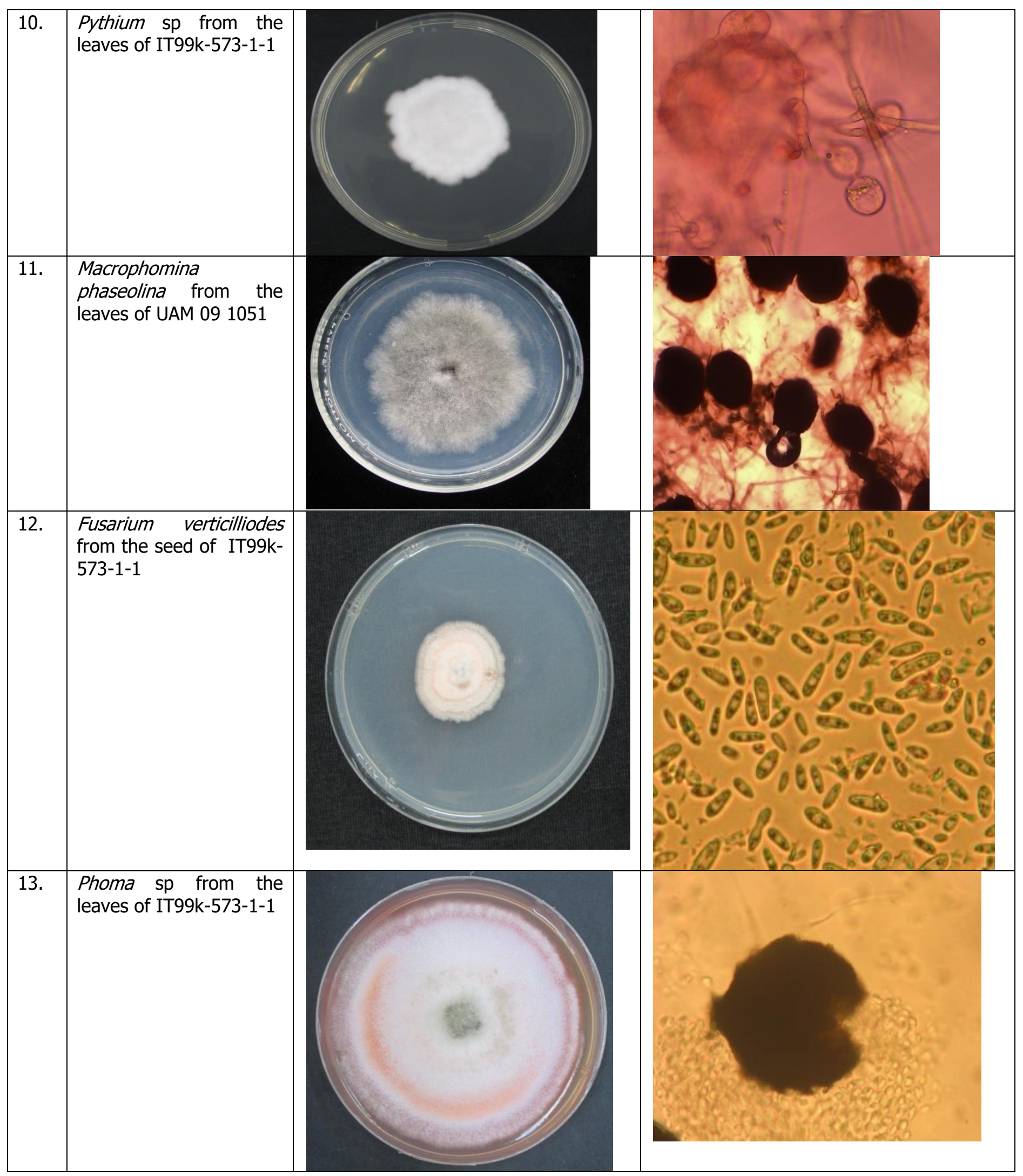




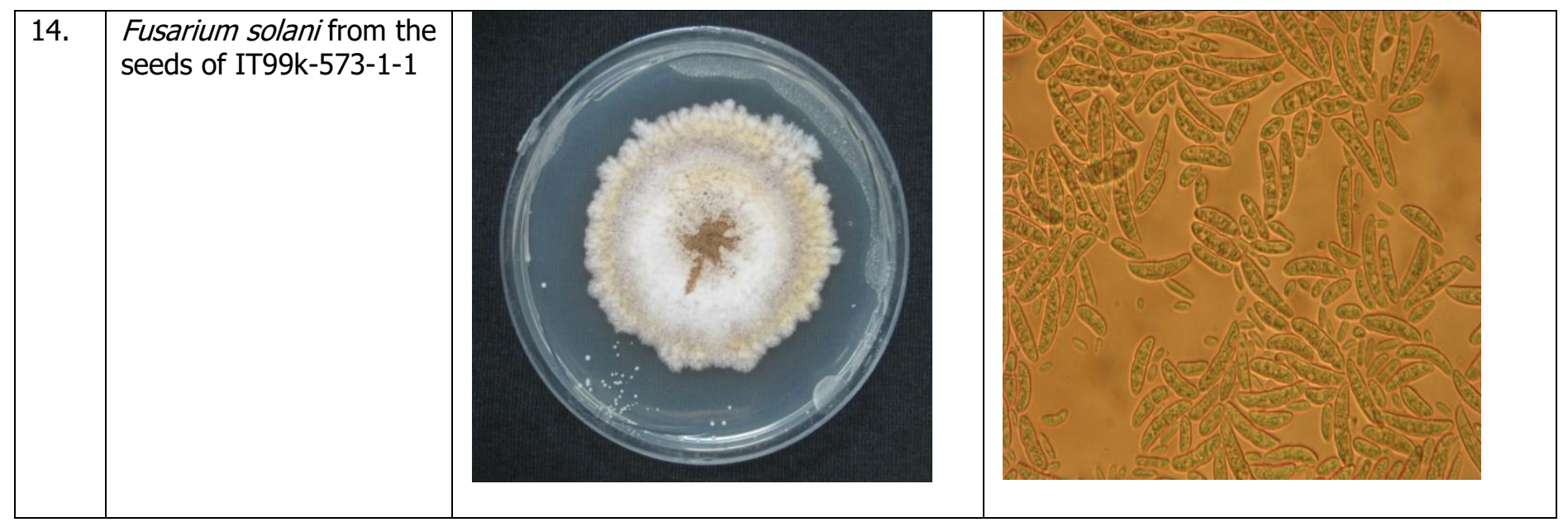

The incidence of leaf spot disease on five varieties of cowpea in Makurdi and Otobi at three growth stages is presented in Table 2.In Makurdi, Cowpea variety UAM 09 1055-6 was highly susceptible to leaf spot disease recording significantly higher $(P \leq 0.05)$ leaf spot incidence of $97.50 \%$ at the vegetative stage compared with leaf spot incidence of IT 99k-573-1$1(16.70 \%)$, IT $90 \mathrm{k}-277-2(10.80 \%)$ and IT $99 \mathrm{k}-$ $573-2-1(9.20 \%)$. The leaf spot incidence of UAM 09 1055-6 and UAM 09 1051-1 progressed significantlyto $100 \%$ and $99.20 \%$ respectively at flowering and pod stages in both locations. On the average, cowpea variety IT 99k-573-1-1, IT 99k-573-2-1 and IT 90k-277-2 were classified as moderately resistant in Makurdi with a mean incidence of $22.23 \%, 16.97 \%$ and $16.67 \%$ respectively which was significantly $(P \leq 0.05)$ lower compared with the mean leaf spot incidence recorded on UAM 09 1051-1 (41.67\%) classified as Moderately susceptible and UAM 09 1055-6 (99.17\%) classified as Highly susceptible. In Otobi, all the cowpea varieties screened were classified as Susceptible to leaf spot incidence with the exception of variety IT 90k-277-2 which was classified as Moderately susceptible to leaf spot disease.

Table 2: Incidence of leaf spot disease on five varieties of cowpea in Makurdi and Otobi

\begin{tabular}{llccccccc}
\hline $\begin{array}{l}\text { Cowpea } \\
\text { Varieties }\end{array}$ & \multicolumn{2}{c}{ Vegetative stage } & \multicolumn{2}{c}{ Flowering stage } & \multicolumn{2}{c}{ Pod stage } & \multicolumn{2}{c}{ Mean Reaction class } \\
\cline { 2 - 9 } Makurdi & Otobi & Makurdi & Otobi & Makurdi & Otobi & Makurdi & Otobi \\
\hline IT 99k-573-1-1 & 16.70 & 30.80 & 18.30 & 48.30 & 31.70 & 80.80 & $22.23 \mathrm{MR}$ & $53.30 \mathrm{~S}$ \\
IT 90k-277-2 & 10.80 & 26.70 & 12.50 & 40.00 & 26.70 & 67.50 & $16.67 \mathrm{MR}$ & $44.73 \mathrm{MS}$ \\
UAM 09 1051-1 & 12.50 & 43.50 & 12.50 & 62.30 & 100.00 & 99.20 & $41.67 \mathrm{MS}$ & $68.33 \mathrm{~S}$ \\
UAM 09 1055-6 & 97.50 & 44.20 & 100.00 & 61.70 & 100.00 & 100.00 & $99.17 \mathrm{HS}$ & $68.63 \mathrm{~S}$ \\
IT 99k- 573-2-1 & 9.20 & 30.00 & 11.70 & 40.80 & 30.00 & 82.50 & $16.97 \mathrm{MR}$ & $51.10 \mathrm{~S}$ \\
\hline FLSD (0.05) & 9.22 & 12.76 & 9.20 & 12.88 & 16.10 & 10.49 & & \\
\hline
\end{tabular}

$\mathrm{MR}=$ Moderately resistance, $\mathrm{MS}=$ Moderately susceptible, $\mathrm{HS}=$ Highly susceptible $\mathrm{S}=$ Susceptible

Table 3 shows the pooled emergence and growth characteristics of Cowpea varieties screened for leaf spot disease in Makurdi and Otobi in 2018 cropping season. Variety UAM 09 1051-1 had significantly higher( $\mathrm{P} \leq 0.05)$ emergence of $94.45 \%$ compared with all other cowpea varieties screened at both locations. VaVariety IT 90K 277-2 and IT 99K-573-1-1 recorded $8282.42 \%$ and $80.20 \%$ emergence while variety UAM 0909 1055-6 recorded the least emergence percentage ofof $61.99 \%$. Cowpea variety IT 90K 277-2 had significantly 
higher number of branches and number of leaves compared with all other cowpea varieties screened. Cowpea variety UAM 09 1055-6 attained $50 \%$ flowering earliest in 42.50 days while variety UAM 09 1051-1 attained $50 \%$ flowering in 48.16 days. Variety IT 99K-573-1-1 was significantly taller $(67.29 \mathrm{~cm})$ compared with other cowpea varieties screened while variety IT $90 \mathrm{~K} 277-2$ was the shortest with $60.54 \mathrm{~cm}$.

Table 3: Emergence and Growth characteristics of Cowpea varieties screened for leaf spot disease in Makurdi and Otobi in 2018 cropping season

\begin{tabular}{llllll}
\hline $\begin{array}{l}\text { Cowpea } \\
\text { varieties }\end{array}$ & $\begin{array}{l}\text { Emergence } \\
\text { percentage }\end{array}$ & $\begin{array}{l}\text { Number of } \\
\text { branches }\end{array}$ & $\begin{array}{l}\text { Number of } \\
\text { leaves }\end{array}$ & $\begin{array}{l}\text { Days to 50\% } \\
\text { flowering }\end{array}$ & $\begin{array}{l}\text { Plant height } \\
\text { (cm) }\end{array}$ \\
\hline IT 99k-573-1-1 & 81.58 & 21.87 & 76.93 & 45.50 & 67.29 \\
IT 90k-277-2 & 82.42 & 25.24 & 92.33 & 44.66 & 63.59 \\
UAM 09 1051-1 & 94.45 & 23.55 & 85.00 & 48.16 & 64.56 \\
UAM 09 1055-6 & 61.99 & 21.72 & 75.15 & 42.50 & 64.01 \\
IT 99k- 573-2-1 & 80.20 & 22.79 & 82.50 & 43.66 & 60.54 \\
\hline FLSD(0.05) & 4.33 & 0.02 & 0.11 & 0.01 & 0.01 \\
\hline
\end{tabular}

The yield characteristics of five cowpea varieties screened for leaf spot disease in Makurdi and Otobi is presented in Table 4. One hundred seed weight was not significantly different among the five cowpea varieties in Makurdi. However, one hundred seeds of cowpea variety IT 99k-573-1-1 planted in Otobi weighed significantly ( $P \leq 0.05)$ higher $(19.63 \mathrm{~g})$ than one hundred seeds of all other cowpea varieties in the same location.
Pods of cowpea variety UAM 09 1055-6 in Makurdi weighed significantly $(P \leq 0.05)$ higher $(2.66 \mathrm{~g})$ while the pods of variety IT $99 \mathrm{~K}-573-1-1$ had the least weight of $2.07 \mathrm{~g}$. There was no significant difference in the pod weight of all cowpea varieties in Otobi. Variety IT 99K-573-21 and IT 99K-277-2 produced significantly higher number of seeds per pod while UAM 09 1051-1 had the least number of seeds at both locations.

Table 4:Yield characteristics of Cowpea varieties screened for leaf spot disease in Makurdi and Otobi in 2018 cropping season

\begin{tabular}{|c|c|c|c|c|c|c|c|c|c|c|}
\hline \multirow[t]{2}{*}{$\begin{array}{l}\text { Cowpea } \\
\text { Varieties }\end{array}$} & \multicolumn{2}{|l|}{$\begin{array}{l}100 \text { seed } \\
\text { weight }(\mathrm{g})\end{array}$} & \multicolumn{2}{|l|}{$\begin{array}{l}\text { Pod } \\
\text { weight(g) }\end{array}$} & \multicolumn{2}{|l|}{$\begin{array}{l}\text { Number } \\
\text { of pods }\end{array}$} & \multicolumn{2}{|l|}{$\begin{array}{l}\text { Number } \\
\text { of seeds } \\
\text { per pod }\end{array}$} & \multicolumn{2}{|c|}{$\begin{array}{l}\text { Yield } \\
\text { (Tons/ha) }\end{array}$} \\
\hline & Makurdi & Otobi & Makurdi & Otobi & Makurdi & Otobi & Makurdi & Otobi & Makurdi & Otobi \\
\hline IT 99k-573-1-1 & 15.70 & 19.63 & 2.07 & 2.53 & 29.77 & 12.37 & 12.00 & 12.27 & 1.10 & 0.53 \\
\hline IT 90k-277-2 & 16.85 & 15.27 & 2.55 & 2.37 & 30.17 & 13.20 & 13.50 & 13.30 & 0.80 & 0.75 \\
\hline UAM 09 1051-1 & 15.60 & 15.53 & 2.27 & 2.23 & 28.83 & 11.87 & 9.50 & 10.80 & 1.17 & 0.19 \\
\hline UAM 09 1055-6 & 15.35 & 14.97 & 2.66 & 2.63 & 25.07 & 12.53 & 13.50 & 12.17 & 0.80 & 0.44 \\
\hline IT 99k- 573-2-1 & 15.85 & 15.20 & 2.34 & 1.97 & 30.23 & 12.80 & 16.00 & 12.43 & 1.43 & 0.61 \\
\hline $\operatorname{FLSD}(0.05)$ & NS & 1.27 & 0.04 & NS & 1.27 & 1.43 & 0.52 & 1.29 & 0.76 & 0.30 \\
\hline
\end{tabular}

\section{Discussion}

Four out of the five cowpea varieties screened had emergence percentage higher than the standard emergence percentage of $75 \%$ indicating a high viability. The study showed seed to field transmission of some cowpea fungi. Anjorin and Mohammed (2014) reported that watermelon seeds with higher fungi inoculum recorded lower germination. Cowpea varieties 
were infected by Fusarium verticillioides, Curvularia lunata and Trichoderma viride. Cowpea variety UAM 09 1055-6 had the highest incidence and severity of leaf spot while variety IT 90K-277-2 was the least susceptible to leaf spot. The isolation of Fusarium $s p$ from the infected cowpea leaves suggests the possibility of seed to field transmission of the fungus. Ekhuemelo and Ekefan (2013) reported the possibility of pepper seedling disease from infected seeds. The low incidence of $A$. niger in this study is in contrast with the report of Dania and Arambi (2015) in which A. niger was reported as the predominant fungi of cowpea stored between $5^{\circ} \mathrm{C}$ and $-20^{\circ} \mathrm{C}$ at IITA Ibadan South West Nigeria. The study revealed the presence of $M$. phaseolina a soil and seed borne pathogen that causes damping off, root rot and charcoal rot reported to cause yield losses in Cowpea (Ndiaye et al., 2015). Curvularia $s p, A$. niger, $A$. Flavus have been reported to reduce nutritional quality and viability of seeds. Curvularia $s p$. is also reported to be associated with leaf spots (Ellis and Galvez) and may lead to abnormal seedling emergence (Muhammad et al., 2012). Aspergillus niger causes seed storage rot while $L$. theobromae causes seed decay in dry beans (Ellis and Galvez). Khan and Kumar (1992) also isolated Curvularia lunata, Fusarium spp. from wheat seed. Lasiodiplodia theobromae is reported to cause $95 \%$ fruit rot in fluted pumpkin (Grubben, 2004). The isolation of $A$. tamarii in this study is in line with the report of Chuku (2011) which confirmed $A$. tamari as causal agent of leaf spot of Duranta repens.

The cowpea varieties screened showed different levels of resistance and susceptibility in the two locations. Cowpea variety UAM 09 1055-6 recorded the highest incidence and severity of leaf spot on the field at the various growth stages while variety IT 90K-277-2 had the lowest incidence with variety IT99K-573-1-1 and IT99K573-2-1 having the least severity, indicating that the cowpea varieties have different levels of resistance to leaf spot disease. This may be due to the inherent genetic make-up of the varieties to resist the disease at different levels (Allerd et al., 1992; Sinsiri et al., 2006). Omoigui et al. (2018) reported IT99K-573-1-1 as resistant to Cercospora leaf spot and UAM09-1055-6 as susceptible to Cercospora leaf spot in Makurdi. The isolation of these fungi from cowpea leaves suggests that several other fungi could be responsible for leaf spot disease in cowpea. This indicates a suspicion of new emerging fungi initiating leaf spot on cowpea apart from Pseudocercospora cruenta causal agent of Cercospora leaf spot in the study area. Chuku (2011) earlier observed the incidence of leaf spot through the formation of a disease complex on Duranta repens.

Leaf spot disease had a significant effect on the yield parameters of cowpea. The higher grain yield recorded by variety IT99k-573-2-1 corroborates the findings of Musa et al (2018) which recorded higher grain yield from IT99k573-2-1 and IT99k-573-1-1 than the yield of UAM 09-1051-1 at Kano. This study showed significant difference in number of pod, pod length and number of seeds per pod among cowpea varieties screened. This is in contrast with the report of Adetumbi et al. (2011) in which pod length and number of seed/pod were not significantly different for two cowpea varieties. The Otobi location recorded more vegetative growth and lower seed yield. Karungi et al. (2000) reported similar trend on cowpea in eastern Uganda and attributed it to heavy rainfall. Chuku (2011) also reported higher incidence of leaf spots in Duranta repens L. due to high humidity during the rainy season in Rivers State Nigeria. Basaran et al. (2011) also reported significant differences in the yield and yield parameters of cowpea genotypes assessed in different locations in Turkey due to differences in temperature.

\section{Conclusion}

The study concludes that cowpeavariety UAM 09 1051-1 had the most viable seeds as it had the highest emergence percentage on the field. Fungi infecting the cowpea seedlings were Fusarium verticillioides, Curvularia lunata, Aspergillus tamarii Kite, Lasiodiplodia theobromae, Aspergillus flavus Link and Aspergillus niger van Tiegh, Pythium sp, Fusarium solani, Macrophomina phaseolina and Phoma sp. Variety UAM 09 1055-6 had the highest incidence and severity of leaf spot while variety IT $90 \mathrm{~K}-277-2$ was the least susceptible to leaf spot disease.

\section{References}


Adetumbi, A.J., Alamu, O., Teixeira de Silva, J.A. (2011). Cowpea (Vigna unguiculata L. Walp) seed germination Indices and yield as affected by length of Storage. Seed Sci. and Biotech 5(1): 11-14.

Agber, P.I., Ajon, A.T. and Ugese F.D. (2017). Effect of cover management practices on erosion, soil properties and maize performance under natural rainfall in Makurdi, Benue State. Nig. J. of Agric, Env. and Bioreseach. Vol. 2(4): 113-125.

Allerd, R.W., Zhang, Q., Maroof, M.A.S. And Mouna, O.M. (1992). Evolution of multilocus genetic structure in an experimental barley population. Genetics Vol. 131 (4): 957-969.

Anjorin, S.T. and Mohammed, M. (2014). Effect of seed borne fungi on germination and seedling vigour of water melon (Citrullus lanatus thumb). Afr. J. of Plant Sci. 8(5):232-236.

Basaran, U., Ayan, I., Acar, Z., Mut, H. and Asci, O. O. (2011). Seed yield and agronomic parameters of cowpea (Vigna unguiculata L.) genotypes grown in the Black Sea region of Turkey. Afr. J. of Biotech. 10 (62): 13461-13464.

Boa, E. (2014). Cercospora leaf spot of cowpea Mycosphaerella cruenta. Africa Soil Health Consortium 2pp.

Chuku, E.C.(2011). Preliminary Studies on the Agronomy, Diseases, Pests and Fungal Flora of Duranta repens Linn in Rivers State, Nigeria.Nig. J. of Plant Prot. 25(1): 117-126.

Dania, V.O. and Arabambi, B.O. (2015). Effect of Storage Conditions on incidence of seed-borne fungi of cowpea (Vigna unguiculata (L.) Walp) and their control with botanicals. Nig. J. of Plant Prot. 29: 73-85.

Dugje, I. Y.; Omoigui, L. O.; Ekeleme, F.; Kamara, A. Y.; Ajeigbe, H. (2009). "Farmers' Guide to Cowpea Production in West Africa". International Institute of Tropical Agriculture. Ibadan, Nigeria. 19pp.

Ekhuemelo, C. and Ekefan, E.J. (2013). Seed borne fungi of Chilli Pepper (Capsicum frutescens) from pepper producing areas of
Benue State, Nigeria. Agric. and Bio. J. of North America, 4(4):370-374.

Ellis, M.A and Galvez, G.E. (1980). Seed pathology In: Schwartz, H. F., Galvez E., Guillermo, E. (eds.). Bean Production Problems: Diseases, Insect, soil and Climatic constraints of Phaseolus vulgaris. Centro International de Agricultura Tropical (CIAT), Cali, CO. p 301-314.

Grubben, G.J.H. (2004). Gardening. In: Plant resources of tropical African Vegetables by Grubben, G.T.H and Denton, O.A. (eds.) 667 pp.

Karungi, J, Adipala E, Ogenga-latigo, M.W., Kyamanywa, S, Oyobo N, Jackai L.E.N. (2000). Pest management in cowpea. Part 2. Integrating planting time, plant density and insect application for management of cowpea field insect pests in eastern Uganda. Crop Prot. 19: 237- 245.

Khan, M. I. and Kumar, R. (1992). Antifungal activity of leaf extract of Neem on seed mycofloraof wheat.Indian J. of Seed Abs. 15(7): 299.

Mehrotra, R.S. and Aggarwal, A. (2003). Plant Pathology. Teta Mc Graw-hill publishing company New Delhi second edition p 254.

Muhammad, I., Anwar, S.A., ul-Haque, M. I., Azar I., Nazir A. and Arain, M. A. (2012). Seedborne fungi associated with cauliflower seeds and their role in seed germination Pak. J. of Phytopath. 24(1): 26-31.

Musa, M. Tadda S.A. and Mahadi,M. (2018). Growth and yield response of Cowpea (Vigna unguiculata L. Walp) as affected by Phosphorus levels and bradyrhizobial strains in

Kano State, Nigeria. Nig. Agric. J. 49(1): 172180.

Ndiaye, M., Sarr, M.P., Cisse, N. and Ndoye, I. (2015). Is the recently described Macrophomina pseudophaseolina pathogenically different from Macrophomina phaseolina? Afr. J. Microbiol. Res. 9 (45): 2232-2238

Neya, B.J.,Zida, P.E., Sereme, D.,Lund, O.S. and Traore, O.(2015). Evaluation of yield Losses Caused by Cowpea Aphid-borne mosaic virus (CABMV) in 21 Cowpea (Vigna unguiculata (L.) Walp) Varieties in Burkina Faso. Pak. J. of Bio. Sci. 18:304-313. 
Oladiran, A.O. (1983). Studies on the diseases of cowpea (Vignaunguiculata L. Walp). Ph.D Thesis. P 225.

Omoigui, L. O., Arrey, M. O., Kamara, A. Y., Danmaigona, C. C., Ekeruo, G. and Timko, M. P.(2019). Inheritance of resistance to Cercospora leaf spot disease of cowpea [Vigna unguiculata (L.) Walp]. Euphytica 215(5):101112.

Onuegbu, B. A. and Emiri, U.N. (2011). Studies on the germination and leaf spot disease control in fluted pumpkin (Telferiaoccidentalis) in Ndele, Rivers state, Nigeria. Nig. J. of Plant Prot. 25 (1):139-148.
Sinsiri, N., Loahasiriwong, S., Jogloy, S. T.B. And Saksirirut, W. (2006). A Variet al Screening of Cowpea Cultivars (Vignaunguiculata) For High Resistance to Pseudocercosporacruenta

(Sacc.) Deighton in Northeast Thailand. Pak. J. of Bio. Sci. 9(4): 641-648.

Watanabe, T. (2010). Pictorial atlas of soil and seed fungi: Morphologies of cultured fungi and key to species, 3rd edition. American Phytopathology Society press, United State of America. p404. 